
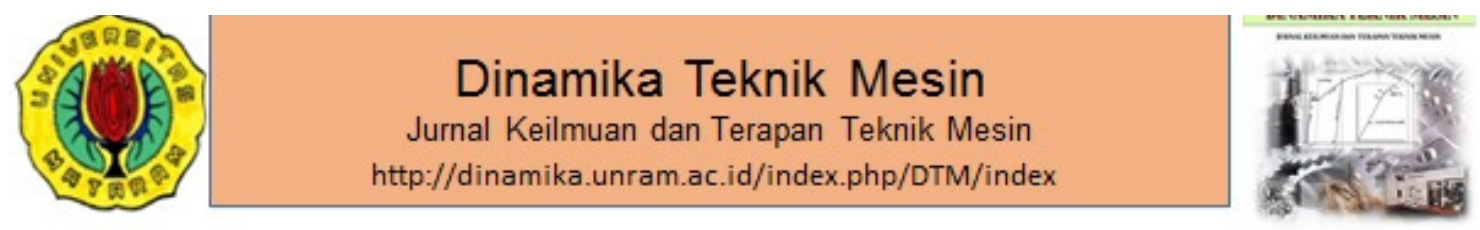

\title{
Simulasi tegangan pada pengaruh putaran roda terhadap speed bump menggunakan metode FEM
}

\section{R. Hidayat, M.B. Haryono*}

Teknik Mesin Fakultas Teknik Universitas Pancasakti Tegal, Jln. Halmahera Km 1 Mintaragen, Tegal Timur, Kota Tegal, Kode Pos : 52121, Telp. (0283) 351082;.

*Email: haryono.upstegal@gmail.com

\section{ARTICLE INFO}

Article History:

Received 2 May 2018

Accepted 23 May 2018

Available online 1 July 2018

Keywords:

Tires

High speed bump

Tires speed

Load

Stress

\section{ABSTRACT}

The interaction between tires and the road surface is very important because it can reduce the risk of accidents due to the tire damage. This research investigated the stress distribution as a result on pressure of tires rolling across speed bump. The research methode used solid work and abaqus application to simulation, the paramaters on research used variation on high speed bump (75 mm, $120 \mathrm{~mm}$ and $160 \mathrm{~mm}$ ) and tires speed $(8,20$ and $30 \mathrm{~km} / \mathrm{h}$ ). The result showed the higher load recived by tires, the higher stress produced.

\section{PENDAHULUAN}

Ban merupakan salah satu elemen terpenting pada sebuah kendaraan yang berfungsi untuk mengendalikan arah kendaraan. Selain itu, ban juga digunakan sebagai pengganti tenaga mesin, dan sistem redaman / suspensi kendaraan. Penelitian tentang interaksi antara ban dan permukaan jalan di dalam kendaraan sangat penting, hal ini terkait dengan masalah lingkungan serta keselamatan selama berkendara. Menurut fenomena ini, Para peneliti telah banyak melakukan penelitian untuk mengeksplorasi fenomena fisik yang mempengaruhi interaksi.(Wei dkk., 2014)

Hasil penelitian Tang dkk. (2012), distribusi temperatur ban ketika bergulir stabil dengan mengembangkan pendekatan elemen hingga sebagai media untuk mengevaluasi distribusi temperatur ban bergulir secara stabil. Hasil dari penelitian ini secara umum menghasilkan, peningkatan beban normal meningkatkan deformasi elastis yang meningkatkan total kepadatan energi regangan dan suhu. Peningkatan tekanan inflasi menyebabkan penurunan suhu akibat penurunan deformasi elastis. Namun, distribusi temperatur primer ditentukan oleh pembebanan dan tekanan inflasi. Efek tegangan dari ban sangat menurun disebabkan oleh tingkat kekakuan yang tinggi dari tubuh-lapis. Tubuh-lapis keras membawa beban komponen utama yang dapat mempertahankan tegangan yang lebih tinggi sehingga besarnya deformasi elastis 
dan tegangan yang dialami oleh ban berkurang secara signifikan. Oleh karena itu, panas karena efek histeresis di ban menurun dengan meningkatnya tubuh-lapis kekakuan sehingga menyebabkan suhu yang lebih rendah dari ban.

Penelitian dengan sebuah studi elemen hingga yang dilakukan dengan menggunakan sifat material dari literatur. Metode elemen hingga digunakan dengan membandingkan data eksperimen dengan data numeric. Data didapat dari pengujian menggunakan kamera berkecepatan tinggi untuk melacak effect impact untuk mendapatkan kekuatan benturan pada daerah lekukan ban. Metode ini digunakan untuk menilai kinerja ban dalam kasus yang ekstrim dari tumbukan ban. Berdasarkan penelitiaan yang dilakukan dapat disimpulkan metode yang digunakan mampu memprediksi fitur - fitur utama dari tumbukan massa pada ban. Penelitian ini dapat membantu seorang insinyur untuk meningkatkan kinerja roda dalam tahap desain. Hal ini dapat menyebabkan respon lebih baik secara keseluruhan roda dan sistem suspensi, dengan implikasi untuk keselamatan sistem transportasi (Neves dkk, 2010)

Dubois dkk. (2012) melakukan penelitian yang berkaitan dengan studi numerik ban kontak / jalan. Sebuah metode dua skala yang digunakan untuk memecahkan masalah kontak antara permukaan jalan multi - kekasaran dan elastis setengah ruang. Metode ini telah digunakan dengan sukses untuk permukaan kasar ideal. Namun, untuk aplikasi yang efisien untuk permukaan diperlukan partisi yang sesuai permukaan. Hasil pada skala ini dianggap dapat diterima terutama ketika metode yang dikembangkan jauh lebih menghemat waktu. Perhitungan kontak ban dengan jalan dalam perhitungan waktu yang wajar hanya dengan metode multi-kekasaran. Distribusi tekanan pada permukaan jalan dievaluasi melului tekstur jalan yang berbeda. Dalam pekerjaan kerangka ban / jalan, permukaan kontak harus cukup untuk memprediksi suara frekuensi rendah yang dihasilkan oleh getaran. Distribusi tekanan awal dapat digunakan untuk memperkirakan permukaan deformasi ban selama bergulir, yang mempengaruhi tekanan angin ban.

Penelitian menggunakan metode elemen hingga pada model ban, pengujian tersebut dapat dilakukan secara virtual. Sebuah model elemen hingga dikembangkan secara khusus untuk tujuan ini menggunakan integrasi eksplisit dalam software ABAQUS. Penyelidikan menunjukkan meningkatnya ketinggian rintangan jalan, mengakibatkan amplitudo resonansi respon kekuatan poros serta deformasi ban menjadi lebih besar di kedua arah longitudinal dan vertical. (Wei dkk., 2014)

Fitur dinamis dari tapak dapat mempengaruhi kekuatan kontak dan kontak kekakuan selama proses deformasi local terjadi. Hal ini dilakukan menggunakan simulasi kontak secara rinci antara lapisan elastis dan permukaan jalan kasar menggunakan model kontak domain numerik yang dikembangkan sebelum waktunya. (Winroth dkk., 2014)

Zhao dkk. (2014) telah melakukan penelitian tentang menghitung besar gaya kontak yang terjadi pada ban pada yang jalan berpasir dengan menggunakan penggabungan metode elemen diskrit dan metode elemen hingga melalui traksi kinerja ban di bawah nilai tergelincir berbeda (0\%, 10\%, 20\%, 30\%, 40\%, $50 \%$ dan $60 \%$ ). Hasil penelitian menunjukkan bahwa secara keseluruhan kecendurungan drawbar menarik dan melawan perbandingan slip dengan baik.

Penelitian yang akan dilakukan untuk mengetahui pengaruh ketinggian polisi tidur dan kecepatan putaran terhadap tegangan yang dihasilkan. Ketinggian polisi tidur yang diterapkan dengan variasi ketinggian $75 \mathrm{~mm}$, $120 \mathrm{~mm}$, dan $160 \mathrm{~mm}$. Peraturan kementerian perhubungan tentang ketinggian polisi tidur adalah dengan ketinggian $120 \mathrm{~mm}$. Variasi ketinggian polisi tidur $75 \mathrm{~mm}$ dan $160 \mathrm{~mm}$ digunakan untuk menbandingkan dengan ketinggian polisi tidur yang sesuai aturan untuk mengetahui efektifitas dari variasi ketinggian polisi tidur dalam meningkatkan keselamatan dan kesehatan bagi pengguna jalan.

\section{METODE PENELITIAN}

Metode penelitian ini menggunakan metode simulasi, adapun langkah-langkah simulasi sebagai berikut

1. Simulasi pertama ban diberikan tekanan angin sebesar $0.21 \mathrm{MPa}$ seperti layaknya memompa ban. Setelah ban diberi tekanan angin, ban diberikan beban $6.000 \mathrm{~N}$. Beban ini meliputi berat kosong kendaraan dijumlahkan dengan beban maksimal kendaraan kemudian dibagi empat untuk setiap satu ban. Kemudian ban digulirkan melewati polisi tidur dengan variasi ketinggian $75 \mathrm{~mm}, 120 \mathrm{~mm}$, dan $160 \mathrm{~mm}$ yang mana Peraturan Kementerian Perhubungan tentang ketinggian polisi tidur adalah dengan ketinggian $120 \mathrm{~mm}$. Variasi ketinggian polisi tidur $75 \mathrm{~mm}$ dan $160 \mathrm{~mm}$ digunakan untuk menbandingkan dengan ketinggian polisi tidur yang sesuai aturan untuk mengetahui efektifitas dari variasi ketinggian polisi tidur dalam meningkatkan 
keselamatan dan kesehatan bagi pengguna jalan. Kecepatan yang digunakan $8 \mathrm{~km} / \mathrm{h}$, kecepatan ini digunakan dengan asumsi pengendara menyadari tentang keberadaan polisi tidur sehingga kecepatan yang digunakan pada kecepatan rendah.

2. Simulasi kedua ban diberikan tekanan angin sebesar 0.21 MPa seperti layaknya memompa ban. Setelah ban diberi tekanan angin, ban diberikan beban $6.000 \mathrm{~N}$. Beban ini meliputi berat kosong kendaraan dijumlahkan dengan beban maksimal kendaraan kemudian dibagi empat untuk setiap satu ban. Kemudian ban digulirkan melewati polisi tidur dengan variasi ketinggian $75 \mathrm{~mm}$, yang mana ketinggian ini lebih rendah dibandingkan dengan Peraturan Kementerian Perhubungan No. 3 Tahun 1994. Kecepatan yang digunakan $8 \mathrm{~km} / \mathrm{h}, 20 \mathrm{~km} / \mathrm{h}$, dan $30 \mathrm{~km} / \mathrm{h}$. Kecepatan $8 \mathrm{~km} / \mathrm{h}$ digunakan dengan asumsi pengendara menyadari tentang keberadaan polisi tidur sehingga kecepatan yang digunakan pada kecepatan rendah. Kecepatan $20 \mathrm{~km} / \mathrm{h}$ diasumsikan pengendara terlambat menyadari adanya polisi tidur sehingga kecepatan yang digunakan pada kecepatan sedang karena terlambat menurunkan kecepatan. Sedangkan kecepatan $30 \mathrm{~km} / \mathrm{h}$ diasumsikan pengendara tidak menyadari adanya polisi tidur sehingga kecepatan yang digunakan pada kecepatan tinggi karena tidak menurunkan kecepatan laju kendaraan.

3. Simulasi ketiga ban diberikan tekanan angin sebesar $0.21 \mathrm{MPa}$ seperti layaknya memompa ban.. Setelah ban diberi tekanan angin, ban diberikan beban $6.000 \mathrm{~N}$. Beban ini meliputi berat kosong kendaraan dijumlahkan dengan beban maksimal kendaraan kemudian dibagi empat untuk setiap satu ban. Kemudian ban digulirkan melewati polisi tidur dengan variasi ketinggian $75 \mathrm{~mm}, 120 \mathrm{~mm}$, dan $160 \mathrm{~mm}$ yang mana Peraturan Kementerian Perhubungan tentang ketinggian polisi tidur adalah dengan ketinggian $120 \mathrm{~mm}$. Variasi ketinggian polisi tidur $75 \mathrm{~mm}$ dan $160 \mathrm{~mm}$ digunakan untuk menbandingkan dengan ketinggian polisi tidur yang sesuai aturan untuk mengetahui efektifitas dari variasi ketinggian polisi tidur dalam meningkatkan keselamatan dan kesehatan bagi pengguna jalan. Kecepatan yang digunakan 20 $\mathrm{km} / \mathrm{h}$, kecepatan ini digunakan dengan asumsi pengendara terlambat menyadari adanya polisi tidur sehingga kecepatan yang digunakan pada kecepatan sedang karena terlambat menurunkan kecepatan laju kendaraan.

4. Simulasi keempat ban diberikan tekanan angin sebesar $0.21 \mathrm{MPa}$ seperti layaknya memompa ban. Setelah ban diberi tekanan angin, ban diberikan beban $6.000 \mathrm{~N}$. Beban ini meliputi berat kosong kendaraan dijumlahkan dengan beban maksimal kendaraan kemudian dibagi empat untuk setiap satu ban. Kemudian ban digulirkan melewati polisi tidur dengan variasi ketinggian 120 $\mathrm{mm}$, yang mana ketinggian ini sesuai dengan Peraturan Kementerian Perhubungan No. 3 tahun 1994 tentang pengaturan ketinggian polisi tidur. Kecepatan yang digunakan $8 \mathrm{~km} / \mathrm{h}, 20 \mathrm{~km} / \mathrm{h}$, dan $30 \mathrm{~km} / \mathrm{h}$. Kecepatan $8 \mathrm{~km} / \mathrm{h}$ digunakan dengan asumsi pengendara menyadari tentang keberadaan polisi tidur sehingga kecepatan yang digunakan pada kecepatan rendah. Kecepatan $20 \mathrm{~km} / \mathrm{h}$ diasumsikan pengendara terlambat menyadari adanya polisi tidur sehingga kecepatan yang digunakan pada kecepatan sedang karena terlambat menurunkan kecepatan. Sedangkan kecepatan $30 \mathrm{~km} / \mathrm{h}$ diasumsikan pengendara tidak menyadari adanya polisi tidur sehingga kecepatan yang digunakan pada kecepatan tinggi karena tidak menurunkan kecepatan laju kendaraan.

5. Simulasi kelima ban diberikan tekanan angin sebesar $0.21 \mathrm{MPa}$ seperti layaknya memompa ban. Setelah ban diberi tekanan angin, ban diberikan beban $6.000 \mathrm{~N}$. Beban ini meliputi berat kosong kendaraan dijumlahkan dengan beban maksimal kendaraan kemudian dibagi empat untuk setiap satu ban. Kemudian ban digulirkan melewati polisi tidur dengan variasi ketinggian $75 \mathrm{~mm}, 120 \mathrm{~mm}$, dan $160 \mathrm{~mm}$ yang mana Peraturan Kementerian Perhubungan tentang ketinggian polisi tidur adalah dengan ketinggian $120 \mathrm{~mm}$. Variasi ketinggian polisi tidur $75 \mathrm{~mm}$ dan $160 \mathrm{~mm}$ digunakan untuk menbandingkan dengan ketinggian polisi tidur yang sesuai aturan untuk mengetahui efektifitas dari variasi ketinggian polisi tidur dalam meningkatkan keselamatan dan kesehatan bagi pengguna jalan. Kecepatan yang digunakan $30 \mathrm{~km} / \mathrm{h}$, kecepatan ini digunakan dengan asumsi pengendara tidak menyadari adanya polisi tidur sehingga kecepatan yang digunakan pada tinggi karena tidak menurunkan kecepatan laju kendaraan.

6. Simulasi keenam ban diberikan tekanan angin sebesar $0.21 \mathrm{MPa}$ seperti layaknya memompa ban. Setelah ban diberi tekanan angin, ban diberikan beban $6.000 \mathrm{~N}$. Beban ini meliputi berat kosong kendaraan dijumlahkan dengan beban maksimal kendaraan kemudian dibagi empat untuk setiap satu ban. Kemudian ban digulirkan 
melewati polisi tidur dengan variasi ketinggian $160 \mathrm{~mm}$, yang mana ketinggian ini lebih tinggi dibandingkan dengan Peraturan Kementerian Perhubungan No. 3 tahun 1994. Kecepatan yang digunakan $8 \mathrm{~km} / \mathrm{h}, 20 \mathrm{~km} / \mathrm{h}$, dan $30 \mathrm{~km} / \mathrm{h}$. Kecepatan $8 \mathrm{~km} / \mathrm{h}$ digunakan dengan asumsi pengendara menyadari tentang keberadaan polisi tidur sehingga kecepatan yang digunakan pada kecepatan rendah. Kecepatan $20 \mathrm{~km} / \mathrm{h}$ diasumsikan pengendara terlambat menyadari adanya polisi tidur sehingga kecepatan yang digunakan pada kecepatan sedang karena terlambat menurunkan kecepatan. Sedangkan kecepatan $30 \mathrm{~km} / \mathrm{h}$ diasumsikan pengendara tidak menyadari adanya polisi tidur sehingga kecepatan yang digunakan pada kecepatan tinggi karena tidak menurunkan kecepatan laju kendaraan.

Tabel 1. Data Material

\begin{tabular}{llll}
\hline Material & Densitas & $\begin{array}{l}\text { Elastic(MPa) } \\
\text { Khusus rubber-Hyperelastic) }\end{array}$ & Passion Ratio \\
\hline Carcas & 1200 & 500 & 0,3 \\
Belt & 5900 & 172200 & 0,3 \\
& & $\begin{array}{l}\text { Mooney-Rivlin } \\
\text { C10 }=0.8061\end{array}$ \\
Ruber & \multirow{2}{*}{1400} & C01 1.805 & \\
& & D1 $=0.01$ & \\
\hline
\end{tabular}

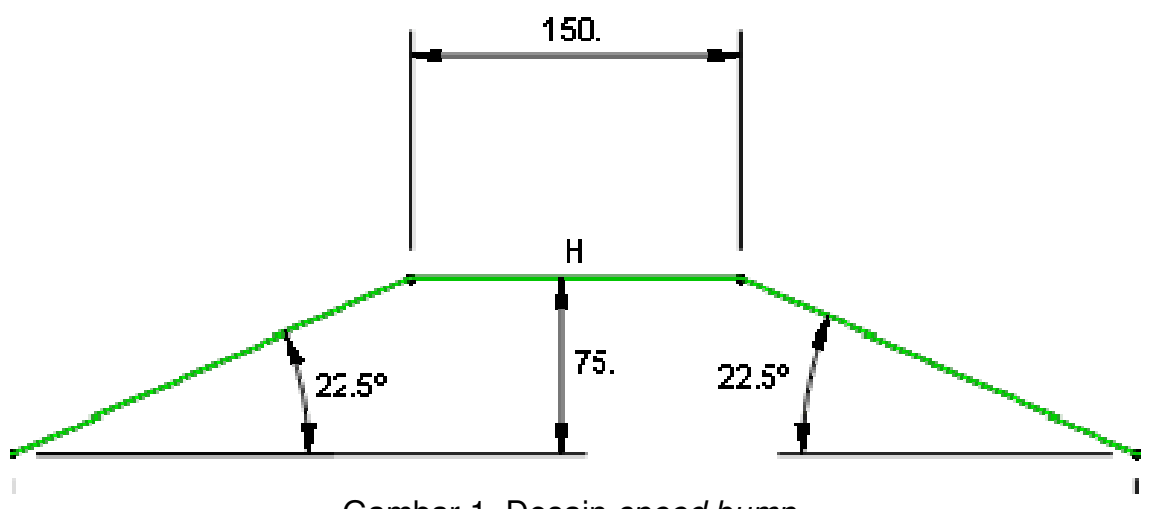

Gambar 1. Desain speed bump

\section{HASIL DAN PEMBAHASAN}

Hasil simulasi pengaruh jarak tempuh tegangan dapat dilihat pada gambar 2. Gambar 2 menunjukkan hubungan antara waktu tempuh terhadap nilai tegangan dari perbedaan ketinggian polisi tidur. Perbedaan ketinggian speed bump tidak berpengaruh terhadap nilai tegangan yang dihasilkan, karena masing - masing mempunyai nilai tegangan yang sama. Nilai tegangan yang dihasilkan pada simulasi ini ditunjukkan pada tabel 2. Tabel 2 merupakan hasil variasi speed bump dengan menggunakan kecepatan $8 \mathrm{~km} / \mathrm{h}$.

Tabel 2. Nilai tegangan pada kecepatan ban $8 \mathrm{Km} / \mathrm{h}$

\begin{tabular}{cccccc}
\hline $\begin{array}{c}\text { Kecepatan } \\
(\mathrm{Km} / \mathrm{h})\end{array}$ & $\begin{array}{c}\text { Tinggi polisi } \\
\text { tidur }(\mathrm{mm})\end{array}$ & $\begin{array}{c}\text { Tegangan } \\
\text { terbesar }(\mathrm{MPa})\end{array}$ & $\begin{array}{c}\text { Waktu } \\
\text { tempuh }(\mathrm{mm})\end{array}$ & $\begin{array}{c}\text { Tegangan terkecil } \\
(\mathrm{MPa})\end{array}$ & $\begin{array}{c}\text { Waktu tempuh } \\
(\mathrm{mm})\end{array}$ \\
\hline 8 & 75 & 1.55 & 3.60 & -0.42 & 2.37 \\
8 & 120 & 1.58 & 3.19 & -0.42 & 2.37 \\
8 & 160 & 1.55 & 3.60 & -0.42 & 2.37
\end{tabular}

Gambar 3 dan 4 menunjukkan hubungan antara waktu tempuh terhadap nilai tegangan s22 dari perbedaan ketinggian speed bump. Perbedaan ketinggian speed bump mempunyai pengaruh terhadap nilai tegangan yang dihasilkan. Tabel 3 dan Tabel 4 merupakan pengaruh kecepatan putar terhadap tegangan s22, Tabel 3 merupakan perbandingan dari 
kecepatan putar $20 \mathrm{~km} / \mathrm{h}$ sedangkan tabel 4 menggunakan kecepatan putar $30 \mathrm{~km} / \mathrm{h}$.

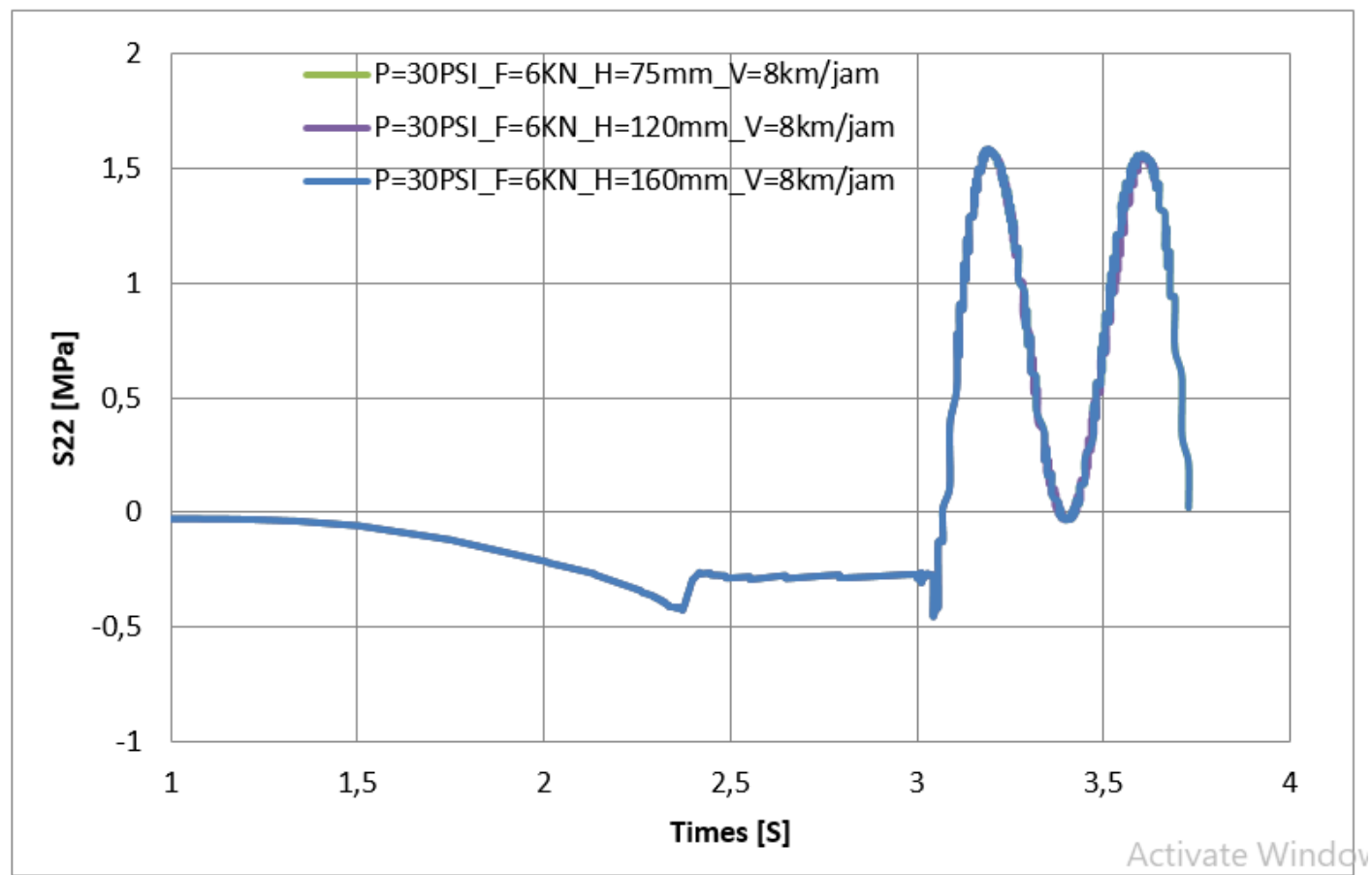

Gambar 2. Hubungan antara waktu tempuh terhadap tegangan s22 pada kecepatan $8 \mathrm{~km} / \mathrm{h}$ dengan variasi ketinggian polisi tidur $75 \mathrm{~mm}, 120 \mathrm{~mm}$, dan $160 \mathrm{~mm}$.

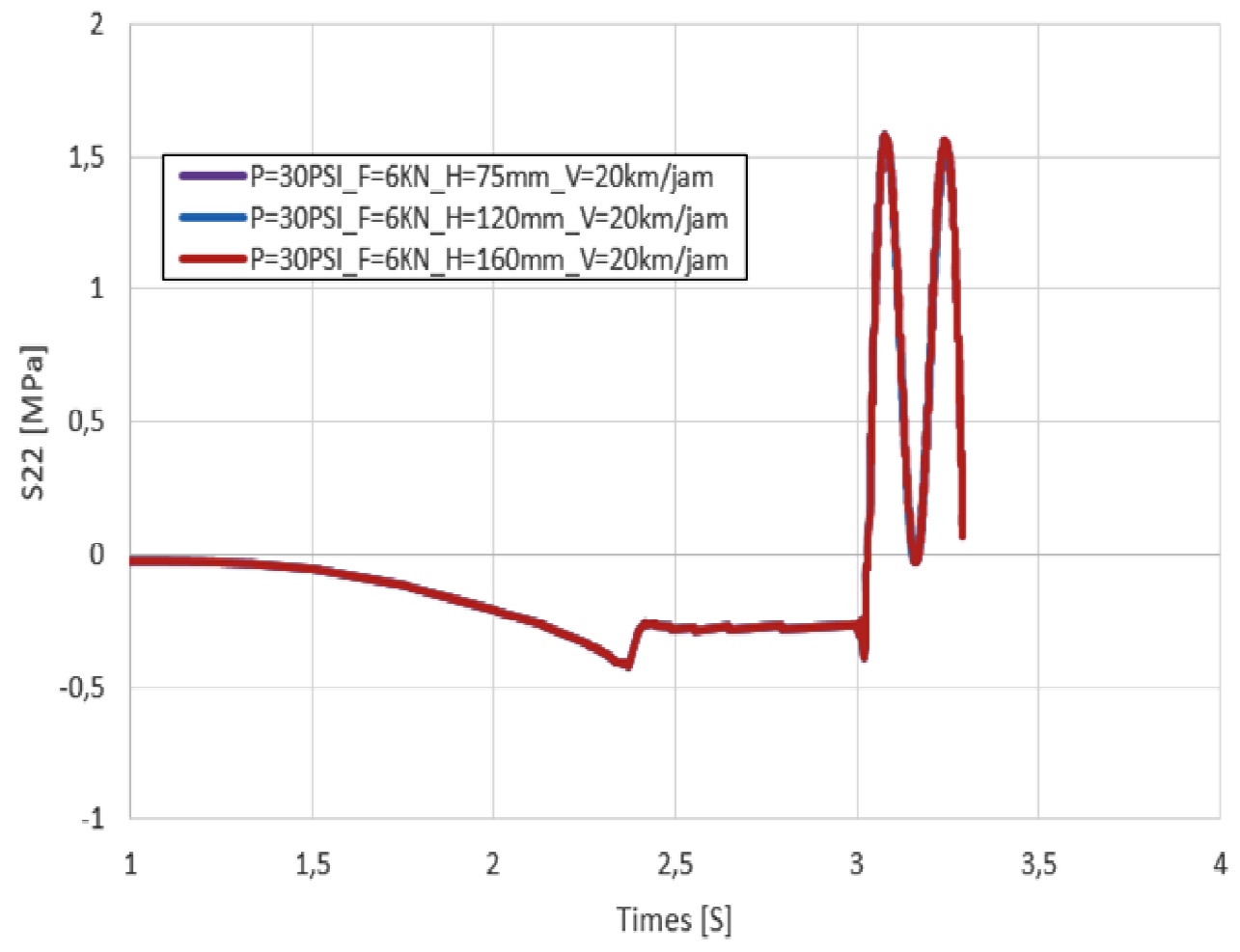


Gambar 3. Hubungan antara waktu tempuh terhadap tegangan s22 pada kecepatan $20 \mathrm{~km} / \mathrm{h}$ dengan variasi ketinggian polisi tidur $75 \mathrm{~mm}, 120 \mathrm{~mm}$, dan $160 \mathrm{~mm}$.

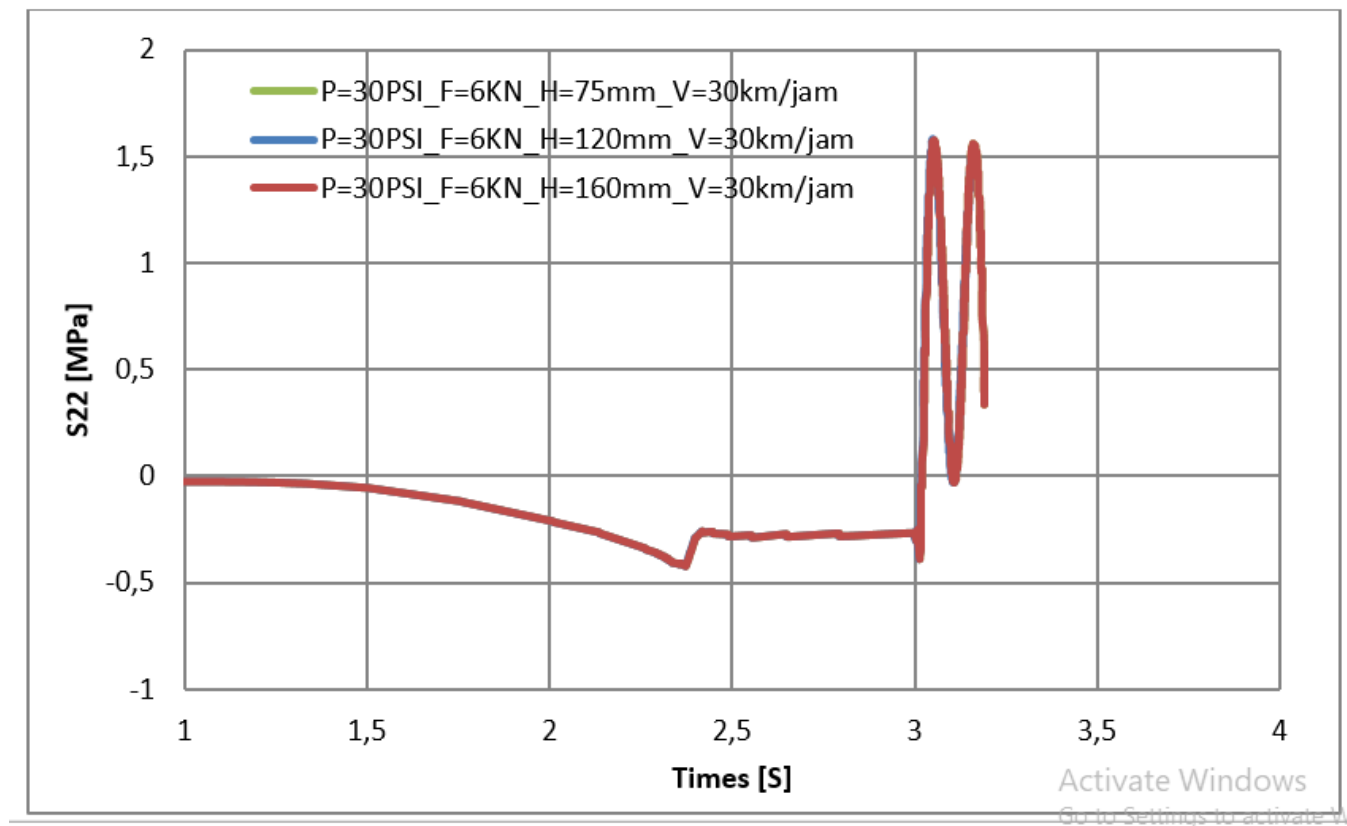

Gambar 4. Hubungan antara waktu tempuh terhadap tegangan s22 pada kecepatan putaran $30 \mathrm{~km} / \mathrm{h}$ dengan variasi ketinggian polisi tidur $75 \mathrm{~mm}, 120 \mathrm{~mm}$, dan $160 \mathrm{~mm}$.

Tabel 3. Nilai tegangan pada kecepatan ban $20 \mathrm{Km} / \mathrm{h}$

\begin{tabular}{cccccc}
\hline $\begin{array}{c}\text { Kecepatan } \\
(\mathrm{Km} / \mathrm{h})\end{array}$ & $\begin{array}{c}\text { Tinggi polisi } \\
\text { tidur }(\mathrm{mm})\end{array}$ & $\begin{array}{c}\text { Teg terbesar } \\
(\mathrm{Mpa})\end{array}$ & $\begin{array}{c}\text { Waktu } \\
\text { tempuh } \\
(\mathrm{mm})\end{array}$ & $\begin{array}{c}\text { Teg terkecil } \\
(\mathrm{Mpa})\end{array}$ & $\begin{array}{c}\text { Waktu tempuh } \\
(\mathrm{mm})\end{array}$ \\
\hline 20 & 75 & 1.56 & 3.24 & -0.42 & 2.37 \\
20 & 120 & 1.58 & 3.07 & -0.42 & 2.37 \\
20 & 160 & 1.56 & 3.24 & -0.42 & 2.37 \\
\hline
\end{tabular}

Tabel 4. Nilai tegangan pada kecepatan ban $30 \mathrm{Km} / \mathrm{h}$

\begin{tabular}{cccccc}
\hline $\begin{array}{c}\text { Kecepatan } \\
(\mathrm{Km} / \mathrm{h})\end{array}$ & $\begin{array}{c}\text { Tinggi polisi } \\
\text { tidur }(\mathrm{mm})\end{array}$ & $\begin{array}{c}\text { Teg terbesar } \\
(\mathrm{Mpa})\end{array}$ & $\begin{array}{c}\text { Waktu } \\
\text { tempuh } \\
(\mathrm{mm})\end{array}$ & $\begin{array}{c}\text { Teg terkecil } \\
(\mathrm{Mpa})\end{array}$ & $\begin{array}{c}\text { Waktu tempuh } \\
(\mathrm{mm})\end{array}$ \\
\hline 30 & 75 & 1.54 & 3.16 & -0.42 & 2.37 \\
30 & 120 & 1.58 & 3.05 & -0.42 & 2.37 \\
30 & 160 & 1.55 & 3.15 & -0.42 & 2.37 \\
\hline
\end{tabular}

Dari data tabel dan grafik diatas menunjukan nilai distribusi tegangan maksimum terjadi pada kondisi simulasi ketinggian speed bump $120 \mathrm{~mm}$ pada kondisi bergulir dengan 
kecepatan 20 dan $30 \mathrm{~km} / \mathrm{h}$ dengan nilai tegangan s22 yaitu $1.58 \mathrm{MPa}$ sedangkan nilai distribusi tegangan s22 minimum dihasilkan nilai yang sama dari masing - masing simulasi yang telah dilakukan yaitu $-0.42 \mathrm{MPa}$ pada waktu tempuh $2.37 \mathrm{~s}$.

\section{KESIMPULAN}

Dari hasil data penelitian pada bagian hasil dan pembahasan maka dapat ditarik kesimpulan sebagai berikut :

1. Berdasarkan simulasi yang dilakukan, kecepatan putaran ban berpengaruh terhadap nilai tegangan s22 yang dihasilkan. Nilai tegangan s22 maksimum terjadi pada kecepatan $20 \mathrm{~km} / \mathrm{h}$ dengan nilai $1.58 \mathrm{MPa}$ pada waktu tempuh $3.05 \mathrm{~s}$ dan nilai tegangan minimum terjadi pada kecepatan $30 \mathrm{~km} / \mathrm{h}$ dengan nilai 1,54 MPa pada waktu tempuh 3.16 s.

2. Polisi tidur yang baik digunakan adalah pada ketinggian $75 \mathrm{~mm}$ dan $160 \mathrm{~mm}$ karena pada kecepatan tertinggi $30 \mathrm{Km} / \mathrm{h}$ masih menunjukkan nilai tegangan yang lebih rendah dibandingkan dengan ketinggian polisi tidur 120 $\mathrm{mm}$ yang sesuai dengan keputusan menteri perhubungan No. 3 tahun 1994.

\section{DAFTAR PUSTAKA}

Dubois G. J., Cesbron H.P., Yin F., AnfossoLedee., 2012, Numerical evaluation of tyre/road contact pressures using amultiasperity approach, Int J Mech Sci, 54, 84-94

Neves R.R.V., Micheli R.R.V., Alves M., 2010, An experimental and numerical investigation on tyre impact, Int $\mathrm{J}$ Impact Eng, 37, 685-69.

Tang T., Johnson D., Smith R.E., 2012, Simulation of thermal signature of tires and tracks, (NDIA Ground Vehicle Systems Engineering and Technology Symposium, Modeling \& Simulation, Testing and Validation (MSTV) MiniSymposium, Michigan August, 14-16.

Wei C., Olatunbosun O.A., 2014, Transient dynamic behaviour of finite element tire traversing obstacles with diferent heights, Journal of Terramechanics, 56, 1-16.

Winroth J, P.B.U., Andersson., Kropp W., 2014, Importance of tread inertia and damping on the tyre/road contact stiffness, Journal of Sound and Vibration, Letter 333, 5378-5385.

Zhao C., Zang M., 2014, Analysis of rigid tire traction performance on a sandy soil by 3D finite element-discrete element method, Journal of Terramechanics, 55, 29-37. 